\title{
Sera Koșullarında Farklı Tuzluluk Düzeyindeki Sulama Sularının Domates Bitkisinin Kök Gelișimi Üzerine Etkisi
}

\author{
Selçuk ÖZER' ${ }^{1, *}$ (DD \\ Ozan ÖZTÜRK' (ID) \\ Ülviye ÇEBI' ID \\ Süreyya ALTINTAȘ \\ Engin YURTSEVEN² ID
}

'Atatürk Toprak, Su ve Tarımsal Meteoroloji Araștırma Enstitüsü, Kırklareli
${ }^{2}$ Ankara Üniversitesi Ziraat Fakültesi Tarımsal Yapılar ve Sulama Bölümü, Ankara
${ }^{3}$ Namık Kemal Üniversitesi Ziraat Fakültesi Bahçe Bitkileri Bölümü, Tekirdağ

*Sorumlu yazar e-mail (Corresponding author e-mail): selcuk.ozer@tarimorman.gov.tr

Geliș tarihi (Received): 25.04.2019

Kabul tarihi (Accepted): 19.07.2019

DOI: $10.21657 /$ topraksu. 655577

Öz

Bu çalıșma, Atatürk Toprak, Su ve Tarımsal Meteoroloji Araștırma Enstitüsü uygulama alanında mevcut plastik serada, farklı tuzluluk düzeyindeki sulama sularının domates bitkisinin kök gelișimine etkisini izlemek amacıyla yapıımıștır. Çalıșmada iki farklı tuz konsantrasyonuna sahip sulama suyu (T1: $0.38 \mathrm{dS} \mathrm{m}^{-1}$ ve T2: $\left.5.0 \mathrm{dS} \mathrm{m}^{-1}\right)$ kullanılmıș ve domates bitkisinin kök gelișimi dört farklı derinlikte (0-25, 25-40, 40-55, 55-70, $70-90 \mathrm{~cm}$ ) minirhizotron kamera yardımıyla izlenmiștir. Elde edilen kök görüntüleri RootSnap programı yardımıyla analiz edilerek 5 farklı derinlikteki kök miktarları yüzdesel olarak hesaplamıștır. Elde edilen sonuçlara göre; T2 sulama suyu ile sulanan domates bitkisinin kök gelișimi, tuz miktarının yoğunlaștığı 0-25, 25-40 cm'lik toprak katmanında olumsuz olarak etkilenmiș ve buna bağlı olarak kök yüzdesi düșük olmuștur. Kullanılan sulama yöntemi kaynaklı olarak alt katlarda $(40-55,55-70,70-90 \mathrm{~cm})$ tuz birikimi daha düșük seviyelerde olduğundan, kök yüzdesinin arttığı gözlenmiștir. T1 sulama suyu ile sulanan konunun farklı katmanlardaki tuz miktarları kök gelișimini ve su alımını olumsuz yönde etkilemeyecek düzeylerde olduğundan, kök yüzdesi tüm katmanlarda birbirine yakın oranda belirlenmiștir.

Anahtar Kelimeler: Domates, kök izleme, minirhizotron, toprak tuzluluğu

\section{The Effect of Irrigation Water of Different Salinity Level on Root Development of Tomato Plant in Greenhouses Conditions}

\section{Abstract}

The aim of this study is to observe the effect of irrigation water of different salinity level on root development of tomato plant and carried out Atatürk Soil, Water and Agricultural Meteorology Research Institute's Greenhouses. Irrigation water (T1: $0.38 \mathrm{dS} \mathrm{m}^{-1}$ - T2: 5,0.dS $\mathrm{m}^{-1}$ ) with two different amounts of salt was used in the study and the root development of the tomato plant was examined at four different depths $(0-25,25-40,40-55,55-70,70-90 \mathrm{~cm})$ were monitored with the aid of a minirhizotron camera. The obtained root images are analyzed with the help of the RootSnap program to calculate the root quantities in 5 different depths as a percentage.

As a result of the research, the root growth of tomato plant with $\mathrm{T} 2$ irrigation water was adversely affected by salt accumulation in the soil with high salt content $(0-25,25-40 \mathrm{~cm})$ and accordingly root percentage was low. In the low-salt lower layers $(40-55,55-70,70-90 \mathrm{~cm})$, the percentage of root was increased because the salt accumulated in the soil was low. In T1 irrigation water, the percentages 
of roots were obtained in close proximity in each layers, since that would not affect root development and water uptake negatively.

Keywords: minirhizotron, root monitoring, soil salinity, tomato

\section{Gíiș}

Toprakta tuz birikimine sulama suyu niteliğinin etkisi büyüktür. Ancak tuzlanmaya kontrolsüz sulama ile uygulanan fazla su ve uygulanıș biçimi de etkili olmaktadır. Bunlarla birlikte hangi koșulda olursa olsun tuz birikimine bağlı olarak üretim kayıplarının meydana geleceği bir gerçektir. Bu nedenle kayıpların azaltılması için bitki büyüme dönemi, sulama yönetimi, sulama aralığı ve çevre koșulları gibi birçok etmenin bitkisel verim üzerine etkili olduğu göz önüne alınarak kültür bitkilerinin tuz stresi altındaki su kullanım özelliklerinin bilinmesi gerekmektedir.

Bütün kültür bitkileri belli düzeydeki tuzluluğa karșı duyarlıdırlar. Tuzluluğun artması ile belli bir noktadan sonra verimde sürekli bir azalma söz konusudur. Özellikle sebzelerde düșük kaliteli suların kullanılması durumunda bitki özellikleri, verim ve kalitede olușabilecek değișimlerin ve tarım alanlarında ortaya çıkan tuzluluk sorununun belirlenmesi oldukça önemlidir.

Sert ve tropikal iklim olmak üzere geniș bir iklim kușağında yetișen domates toprak istekleri bakımından da seçici bir bitki değildir. Ancak toprak tuzluluğuna karșı orta hassasiyet gösterir ve toprak çözeltisinin EC'si 2.5 dS ml' $^{-1} \mathrm{i}$ geçtiği zaman domateste meyve verimi düșmeye bașlar (Tülücü, 2003). Bunun yanında bitki genetiği ve fizyolojisi bakımından çok fazla bilgi olmasından dolayı domates bitkisi tuzlu alanlarda ve kötü kaliteli sulama suların kullanımında model bitki olarak kullanılabilmektedir (Cuartero ve FernandezMunoz 1999).

Yurtseven vd. (2005) saksıda yetiștirdikleri domates bitkisine 4 farklı tuz düzeyine sahip sulama suyu uygulamıșlardır $(0.25,2.5,5$ ve 10 $\left.\mathrm{dS} \mathrm{m}^{-1}\right)$. Araștırma sonucunda, sulama suyundaki tuzluluğun artması ile verimde düșmelere neden olduğunu bildirmișlerdir. Aynı doğrultuda Reina vd. (2005) sulama suyundaki tuzluluğun artması ile verimde düșmeler olduğunu bildirmiștir. Resticcia vd. (2002) yaptıkları araștırmada, domates sulamasında tuzlu su kullanılması durumunda bitki gelișiminin bozulmaması (verim ve kökyapısının) için sulama suyuna ek olarak yıkama suyu uygulaması yapılmasını önermișlerdir.
Kanada'da yapılan bir araștırmada buğday bitkisinde topraktaki nem miktarının artması ile bitkilerin köklerinin uzunluklarının arttığı ve köklerin daha derine indiğini gözlemlemișlerdir (Entz vd., 1992). Deveciler (2011) mısır sulamasında çizgi kaynaklı yağmurlama sulama sistemini kullanmıșlar ve minirhizotron tekniği ile tespit edilen kök uzunluklarının, uygulanan sulama suyu ile doğru orantııı olarak arttığını gözlemișlerdir.

Tuz stresinin bitkiler üzerindeki etkileri; bitkinin çeșidine, uygulanan tuz çeșidi ile miktarına, uygulanan sulama suyunun kalitesine ve maruz kalma sıklığına bağlı olarak değișmektedir. Tuz stresi, hücre bölünmesini ve uzamasını etkileyerek, bitkilerin kök miktarı tuzlu olan toprak katmanlarında azalmakta ve verimde düșmelere neden olmaktadır (Burssens, 2000).

Klepper ve Taylor (1979) yaptıkları araștırmada, bitkide suyun alınmasında ve tașınmasında kök yüzey alanının önemli bir parametre olduğunu ve diğer önemli parametrelerin ise kök uzunluğu ve kök yoğunluğu olduğunu belirtmișlerdir. Zobel (1975), stres koșulları altında yetiștirilen domates bitkisinin, kontrol bitkilerine göre daha fazla yanal besleyici kök geliștirdiğini bildirmiștir. Papadopoulos ve Rendig (1983)'e göre ise yüksek tuz konsantrasyonlarında domates bitkisi kök gelișimi daha az olurken, tuz konsantrasyonunun azalmasıyla kök yoğunluğu ve su alımı artmıștır. Bitki kökünün bulunduğu katmanlardaki tuzluluk kökün büyümesini kısıtlar. Bunun yanında tuza karșı çok hassas olan köklerde ölü kök uzunluğu artmaktadır (Snapp ve Shennan, 1992). Toprak katmanlarındaki tuzun kök bölgesindeki dağlımı zamana ve yere bağlı olarak değișmektedir. Bitki kök bölgesinin üst kısımlarından alt kısımlarına oranla daha fazla su alımı yapmaktadır, dolayısıyla kök bölgesinin üst kısmındaki tuzluluk verimde daha etkili olmaktadır (Öztürk, 1994). Yaylalı (2007) domates bitkisi sulamasında kullanılan sulama suyundaki tuzluluk artıș ile bitki boylarında azalmalar meydana geldiğini fakat kök uzunluklarının arttığını bildirmiștir.

Geleneksel olarak, köklere erișmek için kaplama, kanal açma ve kazı gibi yıkıcı teknikler kullanılmıștır. Daha yakın zamanda, rizosfer içindeki köklerin 
doğrudan ve tekrarlı gözlemlerine izin vermek için rizotronlar ve minirhizotronlar gibi tahribatsız teknikler geliștirilmiștir (Rewald ve Ephrath, 2013). Minirhizotron tekniği, köklerin yayıldığı ortam boyunca, yerleștirilen șeffaf bir tüp aracılığıyla kökleri yerinde gözlemleme ve kaydetmeye dayanır (Polomski ve Kuhn, 2002). Bu teknikte, aynı kök parçacıkları doğrudan ve tekrarlanabilen ölçümlerle gözlenebilir. Genellikle minirhizotron gözlem tüpleri toprağa dikey $\left(90^{\circ}\right)$ veya açlı olarak monte edilir. Açוlı gözlem tüpleri çoğunlukla $30^{\circ}$ veya $45^{\circ}$ de monte edilir, ancak farklı açılarda yaygındır (Johnson vd., 2001). Elde edilen görüntüler görüntü analiz için geliștirilen yazılımlar sayesinde analiz edilebilmektedir (Lobet ve Périlleux, 2013; Lobet, 2017).

Son yıllarda tarım arazileri ile birlikte yer altı ve yerüstü potansiyel su kaynaklarının sınırlı olduğu dikkate alındığında mevcut kaynakların verimli kullanılmasının yanında alternatif kaynakların değerlendirilmesi özellikle su kısıdının yașandığı bölgelerde oldukça önemlidir. Düșük kaliteli olarak nitelendirilen bu sularla yapılan sulamalar sonucunda içerisinde barındırdıkları fazla miktarda tuzlar toprakta bitki kök bölgesinde birikmekte ve zamanla toprak tuzlu hale gelerek bitki kök gelișimini olumsuz yönde etkilemektedir.

Bu çalıșma, 2016 yllında, Atatürk Toprak, Su ve Tarımsal Meteoroloji Araștırma Enstitüsü uygulama alanında yer alan plastik serada farklı tuzluluk düzeyindeki sulama sularının domates bitkisinin farklı toprak katmalarındaki kök gelișimine etkisini izlemek amacıyla yapılımıștır.

\section{MATERYAL VE YÖNTEM}

\section{Araștırma yeri}

Araștırma Marmara Bölgesinin kuzey kısmında yer alan Kırklareli İlinin 4 km batısında bulunan Atatürk Toprak, Su ve Tarımsal Meteoroloji Araștırma Enstitüsü arazisinde kurulu olan 608 $\mathrm{m}^{2}$ 'lik alana sahip $(76 \mathrm{~m} \times 8 \mathrm{~m})$, kuzey-güney doğrultusunda konumlandırılan yay çatılı plastik örtülü serada yürütülmüștür. Sera toprağının tekstür sınıfi; 0-30 ve 60-90 cm'lik katmanları tın, 30-60 cm'lik katmanı kumlu tın'dır.

Araștırmada bitki materyali olarak "Swanson F1" domates çeșidi kullanılmıștır.

\section{Araștırma konuları}

Sulama suyu tuzlulukları: $T_{1}: E_{w}: 0.38$ dS $\mathrm{m}^{-1}$ ve $\mathrm{T}_{2}: \mathrm{EC}_{\mathrm{w}}: 5.0 \mathrm{dS} \mathrm{m}^{-1}$
Sulama suyu miktarı (mm): Profildeki mevcut nem düzeyi, tarla kapasitesine gelecek șekilde haftada iki kez sulama suyu uygulanmıștır.

Sulama Sistemi: damla sulama denetim birimi, gübre tankı, kum-çakıl filtresi, manometre, vana ve su sayacı ünitelerinden olușturulmuștur, iletim biriminde ise, ana boru, yan borular, lateraller ve damlatıcılar mevcuttur. Çalıșmada sulama suyu olarak $T_{1}$ konulu su Kırklareli Barajından temin edilmiștir. $T_{2}$ konulu sulama suyu, SAR değeri 1'den küçük tutularak 5 tonluk su tankında belli oranlarda $\mathrm{MgSO}_{4}, \mathrm{NaCl}$ ve $\mathrm{CaCl}$ tuzları karıștııılarak elde edilmiștir $\left(5 \mathrm{dS} \mathrm{m}^{-1}\right)$.

Topraktaki tuz konsantrasyonu (0-25, 25-40, 40-55, 55-70, 70-90 cm), saturasyon ekstaktında elektrod yöntemiyle, Sağlam(1994)'e göre belirlenmiștir.

\section{Minirhizotron tekniği ve kök görüntüleme cihazı}

Araștırmada, domates bitkisinin farklı kalitedeki sulama sularında kök sisteminin gelișimi kök görüntüleme cihazı ile izlenmiștir.

Minirhizotron tekniğinin esası: köklerin yayıldığı ortam boyunca, yerleștirilen șeffaf bir tüp aracılığıyla kökleri yerinde gözlemleme ve kaydetmeye dayanır (Polomski ve Kunn 2002). Bu teknikte, aynı kök parçacıkları doğrudan ve tekrarlanabilen ölçümlerle gözlenebilir. Minirhizotronlar genellikle tek yıllık zirai kültür bitkilerinin ve laboratuvar ortamında yetiștirilen bitkilerin kök gözlemlerinde kullanılmaktadır (Box, 1996; Smit vd., 2000).

Bitkilerinin kök sistemlerinin görüntülenmesinde Cl-600 model In-Situ kök görüntüleme cihazı kullanılmıștır. Cihaz $6.4 \mathrm{~cm}$ çapında ve $34.3 \mathrm{~cm}$ uzunluğunda dairesel olarak çalıșan bir tarayıcıdır. Kök tarayıcısının kullanılabilmesi için bitki kök bölgesine $6.4 \mathrm{~cm}$ iç çaplı ve $170 \mathrm{~cm}$ uzunluğunda șeffaf pleksiglass kök görüntüleme tüpleri toprağa 45 derece açıyla yerleștirilmiștir. Șekil 1'de görülen kök izleme kamerasının boyu $35 \mathrm{~cm}$ ve bundan sonraki her derinlik ölçümü için $21 \mathrm{~cm}$ çubuklar kullanılmıștır. Șekil 1 ve Șekil 2'de kök görüntüleme cihazı, pleksiglass tüplerin toprağa konumlandırımasına ve analiz programına ait görüntüler bulunmaktadır.

Domates bitkisinin kök gelișimi dört farklı derinlikte $10-25,25-40,40-55$, 55-70, 70-90 $\mathrm{cm})$ minirhizotron kamera yardımıyla izlenmiștir. Elde edilen kök görüntüleri RootSnap programı yardımıyla analiz edilerek 5 farklı derinlikteki kök miktarları yüzdesel olarak hesaplamıștır. 


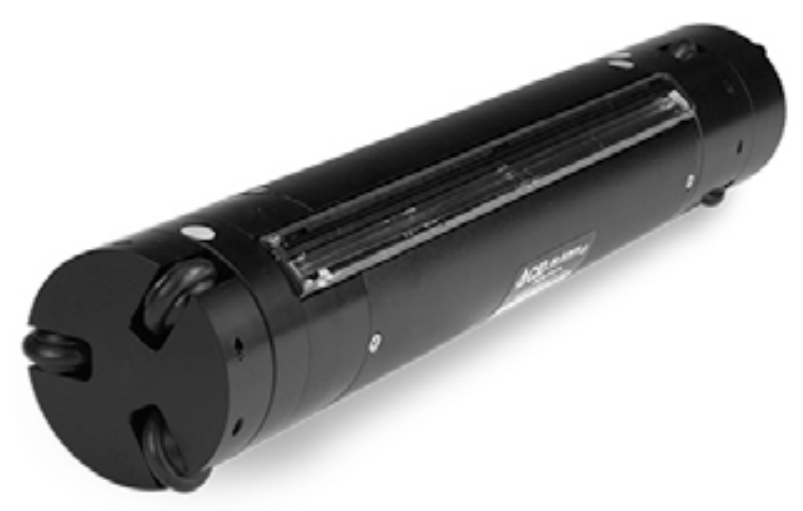

Șekil 1. Kök görüntüleme cihazı ve toprağa konumlandırılması

Figure 1. Root imaging device and location to the soil
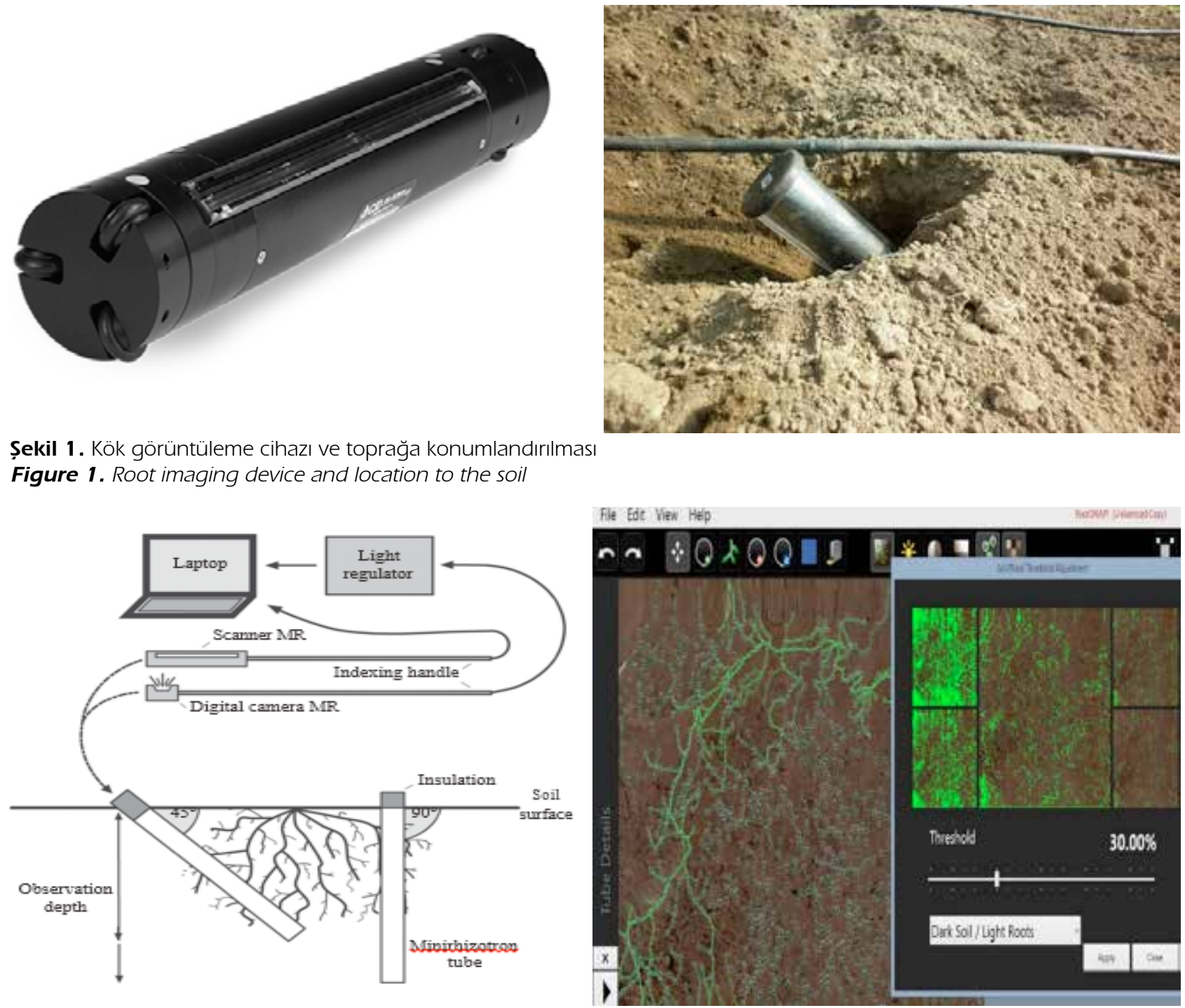

Șekil 2. Kök görüntüleme sistemi ve analiz programı

Figure 2. Root imaging system and analysis program

\section{BULGULAR VE TARTIȘMA}

Çizelge 1'de kök görüntülerinin alındığı toprak katmanlarındaki toprak tuzluluğu ve kök yüzdeleri verilmiștir. Ayrıca Șekil 3'de T1 ve T2 konularından elde edilen kök görüntüleri verilmiștir. Çizelge 1'de yer alan verilere göre;

yüksek tuz konsantrasyon içerikli T2 sulama suyu, toprak profilinin 0-25 ile 25-40 cm'ık katmanında alt katlara oranla daha fazla tuz birikmesine neden olmuștur. Söz konusu derinliklerdeki tuz birikimi kök gelișimini de olumsuz etkilemiș

Çizelge 1. T1 ve T2 konularına ait hesaplanan kök yüzdeleri (\%) ve toprak katmanlarındaki tuzluluk değerleri (dS $\left.\mathrm{m}^{-1}\right)$ Table 1. Analysis of Variance for Grain Nitrogen, Zinc and Iron Concentrations and Grain Yield Values

\begin{tabular}{ccccc}
\hline & \multicolumn{5}{c}{ Konular } \\
\cline { 2 - 5 } Derinlik (cm) & \multicolumn{3}{c}{ T1 } & T2 \\
\cline { 2 - 5 } & $\begin{array}{c}\text { Toprak Tuzluluğu } \\
\left(\mathrm{dS} \mathrm{m}^{-1}\right)\end{array}$ & $\begin{array}{c}\text { Hesaplanan kök } \\
\text { yüzdesi }(\%)\end{array}$ & $\begin{array}{c}\text { Toprak Tuzluluğu } \\
\left(\mathrm{dS} \mathrm{m}^{-1}\right)\end{array}$ & $\begin{array}{c}\text { Hesaplanan kök yüzdesi } \\
(\%)\end{array}$ \\
\hline $70-85$ & 0.47 & 6.88 & 1.14 & 6.53 \\
$55-70$ & 0.47 & 8.57 & 1.14 & 10,92 \\
$40-55$ & 0.37 & 8.63 & 2.30 & 11.13 \\
$25-40$ & 0.36 & 5.64 & 3.90 & 8.26 \\
$0-25$ & 0.38 & 5.41 & 3.21 & 7.51 \\
\hline
\end{tabular}




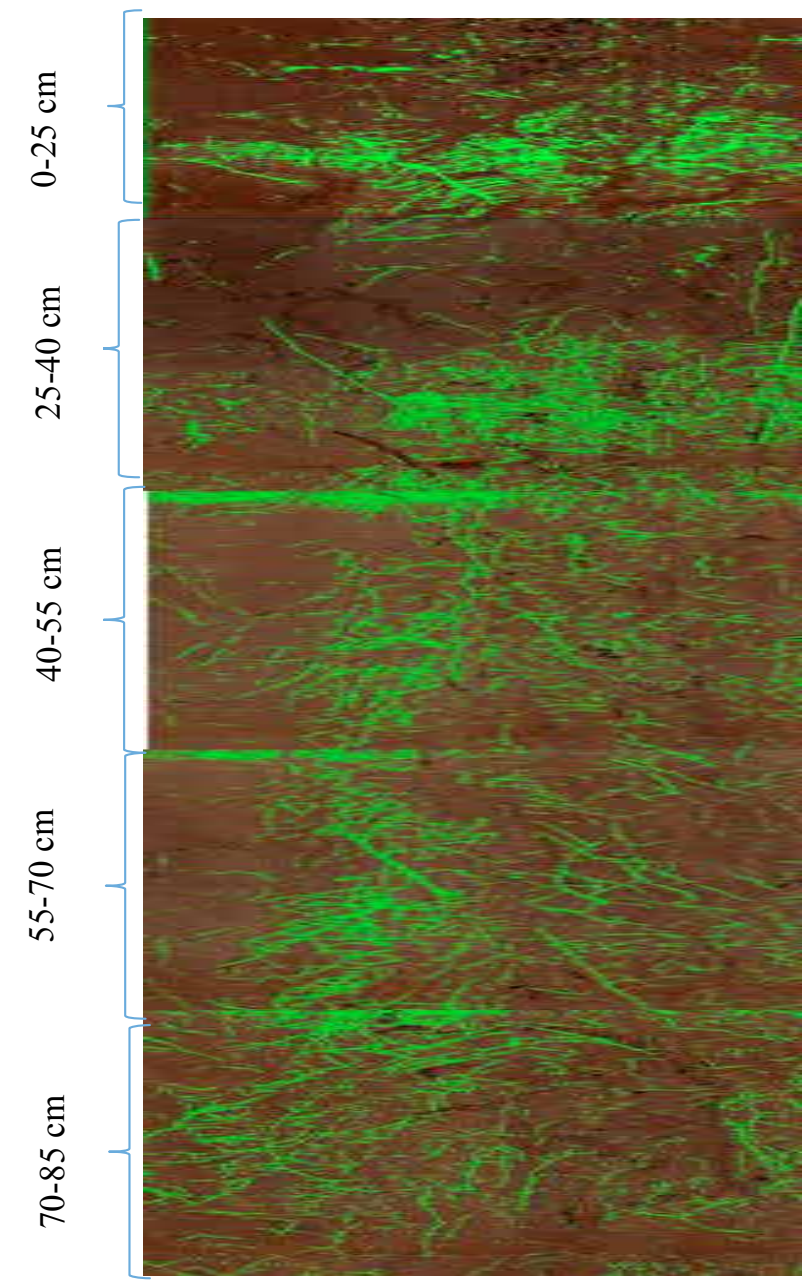

a)

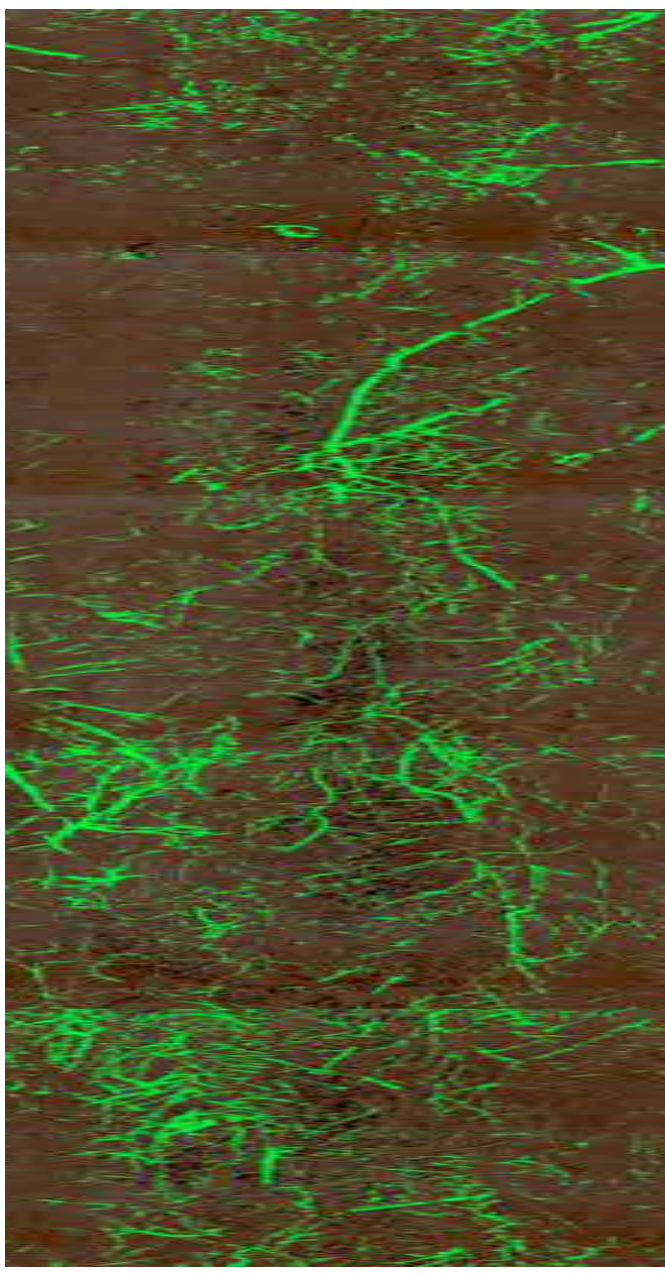

b)

Șekil 3. T1S (a) ve T2S (b) konularında elde edilen kök görüntüleri

Figure 3. Root images obtained from TIS (a) and T2S (b) subjects

ve belirlenen kök yüzdeleri düșük olmuștur. Tuz birikimi alt katmanlarda daha düșük olmuș (40-55, 55-70, 70-90 cm) ve kök gelișimi üst katmanlardaki kadar sınırlanmamıștır. T2 konusunda $0-25, \quad 25-40 \mathrm{~cm}$ derinliklerinde tuzluluk miktarlarının yüksek olması (3.21 ve $3.90 \mathrm{dS} \mathrm{m}^{-1}$ ) ve kök yüzdesinin T1 konusuna göre bir miktar yüksek olması, Snapp ve Shennan (1992)'de açıklanan tuz stresine bağlı olarak ölü kök yüzdesinin artması ile açıklanabilir. T1 sulama suyunda $\left(0.39 \mathrm{dS} \mathrm{m}^{-1}\right)$ ise farklı katmanlardaki tuz miktarları kök gelișimini ve su alımını olumsuz yönde etkilemeyecek düzeylerde olduğundan, kök yüzdesi tüm katmanlarda birbirine yakın oranda elde edilmiștir. Araștırmada elde edilen sonuçlarla paralel olarak, Papadopoulos ve Rendig (1983) yaptıkları araștırmada tuz konsantrasyonunun yüksek olduğu toprak katmanlarında kök gelișiminin sınırlandığını ve tuz konsantrasyonunun azalması ile kök yoğunluğunun arttığını ve su alımının kolaylaștığını bildirmișlerdir. Snapp ve Shennan (1992), bitki kökünün bulunduğu katmanlardaki yüksek tuzluluk kök gelișimini kısıtladığını vurgulamıșlardır. Rhodes, (1992)'ye göre de tuz stresi koșullarının artması durumunda bitki gelișimi ve kök gelișimi yavașlamaktadır.

Çizelge 2'den izleneceği gibi düșük kaliteli sulama suyu ile sulanan domates bitkisinin veriminde azalmalar meydana gelmiștir. Bunun nedeninin düșük kaliteli sular ile sulanan toprakta tuz birikiminin artması ve domates bitkisinin su alımının kısıtlanması olarak gösterilebilir Benzer șekilde bir çok araștırmacı toprakta artan tuz miktarının kök gelișimini engellediğini ve toprak neminin azalması ile kök uzunluklarının arttığını 
bildirmektedir (Papadopoulos ve Rendig 1983, Öztürk 1994, Maggio ve ark. 2007, Yaylalı 2007).

Çizelge 2. $T 1$ ve $T 2$ konularından elde edilen verimler Table 2. Yields obtained from $T 1$ and $T 2$ subjects

\begin{tabular}{cccc}
\hline $\begin{array}{c}\text { Ortalama } \\
\text { Pazarlanabilir } \\
\text { Verim }\left(\mathrm{kg} \mathrm{da}^{-1}\right)\end{array}$ & T1S & T2S & $\begin{array}{c}\text { Oransal verim } \\
\text { azalması }\end{array}$ \\
\cline { 2 - 4 }$(\%)$ & 10943 & 7654 & 30 \\
\hline
\end{tabular}

\section{SONUÇLAR}

Sonuç olarak; domates bitkisinin kökleri tuz miktarı yüksek katmanlarda $(0-25,25-40 \mathrm{~cm})$ gerekli olan sulama suyunu alamadığı için gelișimini yavașlattığı, tuz miktarı daha düșük olan alt katmanlara doğru uzadığını göstermiștir. Kalitesi düșük T2 sulama suyu ile sulanan bitkilerden verim alınmaya devam edilmesi bunu desteklemektedir.

T1 sulama suyu ile sulanan domates bitkisi toprakta biriken yüksek tuz konsantrasyonuna maruz kalmadığı için normal kök gelișimini tüm katmanlarda devam ettirmiștir.

Özellikle kalitesi düșük sulama suları ile sulama yapılması zorunlu olan yerlerde domates yetiștiriciliği yapılacaksa, iyi bir bitki gelișimi, kök gelișimi ve yüksek verim sağlanması için yetișme mevsimi sonunda yıkama yapılması önerilmelidir. Ya da sulama suyuna ek bir yıkama suyu da eklenerek sulama yapılması toprakta tuzluluğun azaltılmasına ve iyi bir kök gelișiminin elde edilmesine yardımcı olacaktır.

\section{TEȘEKKÜR}

Bu çalıșma Atatürk Toprak Su ve Tarımsal Meteoroloji Araștırma Enstitüsü Müdürlüğü'nde 2014-2017 yılları arasında yürütülen ve TAGEM tarafından desteklenen“FarklıTuzlulukDüzeyindeki Sulama Sularının Serada Yetiștirilen Domates ve Brokkoli'nin Verim-Kalite Parametreleri ve Toprak Profili Tuzluluğuna Etkisi " isimli araștırma projesi sonuç raporunun bazı verilerinden hazırlanmıștır.

\section{KAYNAKLAR}

Burssens S, Himanen K, Van de Cotte B, Beeckman T, Van Montagu M, Inzé D, Verbruggen N (2000). Expression of cell cycle regulatory genes and morphological alterations in response to salt stress in arabidopsis thaliana. Planta, 211(5): 632-640.
Box J E Jr ( 1996). Modern Methods of Root Investigations (2nd ed.). In: Waisel Y, Eshel A, Kafkafi U, eds. Plant Roots: The Hidden Half. New York; Marcel Dekker, pp: 193-237.

Cuartero J, Fernandez-Munoz R (1999). Tomato and salinity. Scientia Horticulture, 78: 83-125.

Deveciler M (2011). Farklı yağmurlama sulama düzeylerinin mısır kök gelișimi ve nitrat yıkanması üzerine etkileri. Yüksek Lisans Tezi, Çanakkale Onsekiz Mart Üniversitesi, Tarımsal Yapılar ve Sulama Anabilim Dalı- 76s, Çanakkale.

Entz M H, Gross K G, Fowler D B (1992). Root growth and soil water extraction by winter and spring wheat. Canadian Journal of Plant Science, 72 (4): $1109-1120$.

Johnson M G, Tingey D T, Phillips D L, Storm M J (2001). Advancing fine root research with minirhizotrons. Environ Exp Bot 45: 263-289.

Klepper B ve Taylor H M (1979). Limitations to current models describing water uptake by plant root systems. The Soil-Root Interface / edited by Harley J.L., Russell R.S. London; New York: Published under the aegis of the New phytologist by Academic Press, p. 53-65.

Lobet G, Draye X, Périlleux C (2013). An online database for plant image analysis software tools. Plant methods, 9(1): 38

Lobet G (2017). Image analysis in plant sciences: publish then perish. Trends in Plant Science, 22(7): 559566.

Maggio A, Raimondi G, Martino A, De Pascale S (2007). Salt stress response in tomato beyond the salinity tolerance threshold, Environmental and Experimental Botany,59(3): 276-282.

Öztürk A (1994). Taban suyu derinliği ve sulama suyu kalitesinin biber verimine etkisi. Doktora tezi, Ankara Üniversitesi Fen Bilimleri Enstitüsü, Ankara.

Papadopoulos I ve Rendig V V (1983). Tomato plant response to salinity. Agron. J. 75, 696-700.

Polomski J ve Kuhn N (2000). Kahlschlagbedingte Vera“ nderungen im Wurzelraum eines Buchenniederwaldes auf Rendzina. 10. Borkheider Seminar zur Oekophysiologiedes Wurzelraumes. Stuttgart, Germany: BG Teubner, pp 6571 .

Reina-Sanchez A, Romero-Aranda R, Cuartero J (2005). Plant water uptake and water use efficiency of greenhouse tomato cultivars ırrigated with saline water. Agricultural Water Management, 78: 54-66.

Rewald B, Ephrath J E (2013). Minirhizotron techniques. Plant roots: The hidden half, 42, 1-15.

Sağlam M T (1994). Toprak ve suyun kimyasal analiz yöntemleri. Trakya Üniversitesi Tekirdağ Ziraat Fakültesi Yayınları, Tekirdağ

Smit A L, George E, Groenwold J (2000). Root observations and measurements at (transparent) interfaces with soil. In Root methods (pp. 235-271).

Snapp S S, ve Shennan C (1992). Effects of salinity on root growth and death dynamics of tomato, Lycopersicon esculentum Mill. New phytologist, 121(1): 71-79. 
Tülücü K (2003). Özel Bitkilerin Sulanması. Çukurova Üniversitesi Ziraat Fakültesi Tarımsal Yapılar ve Sulama Bölümü. Genel Yayın No: 254, Adana.

Yaylalı i K (2007). Değișik tuz konsantrasyonuna sahip farklı sulama suyu uygulamalarının domateste verim ve kalite üzerine etkileri. Doktora tezi, Selçuk Üniversitesi Fen Bilimleri Enstitüsü, Konya.
Yurtseven E, Kesmez G D, Ünlükara A (2005). The effects of water salinity and potassium levels on yield, fruit quality and water consumption of a native central anatolian tomato species (Lycopersicon Esculentum). Agricultural Water Management, 78:128-135.

Zobel R L (1975). The genetics of root development. The development and function of roots, 261-275. 